\title{
High specific energy Lithium Sulfur cell for space application
}

\author{
Bruno Samaniego ${ }^{(1)}$, Emmanuelle Carla $^{(1)}$, Laura O’Neill ${ }^{(2)}$, Maria Nestoridi ${ }^{(3)}$ \\ (1) Airbus DS France, 31 rue des Cosmonautes 31402 Toulouse France, Email: emmanuelle.carla@airbus.com; \\ bruno.samaniego@airbus.com \\ (2) OXIS Energy England, E1 Culham Science Centre OX14 3DB Abingdon, Oxfordshire UK, \\ Email:Laura.ONeill@oxisenergy.com \\ (3)ESA-ESTEC,Keplerlaan 1,2200AG Noordwijk, NL,E-mail: Maria.Nestoridi@esa.int
}

\begin{abstract}
The battery energy density remains a key parameter accounting for the satellite mass budget. As illustration to this, the rechargeable battery still represents 100 to 200 of kilograms for a typical Eurostar 3000 satellite, which can represent up to $5 \%$ of the total mass, and about 100 kilograms for the next meteorological satellite program MetOp-SG. Any reduction in weight in these applications has therefore significant financial benefits, considering that the launch cost for such a satellite can be around $10 \mathrm{k} € / \mathrm{kg}$.

Lithium-ion technology represented a revolution in terms of specific energy compared to $\mathrm{Ni}-\mathrm{Cd}$ and is currently the most used and well suited for spacecraft. But it has also many drawbacks like price, some safety issues and its toxicity. Lithium-Sulfur ( $\mathrm{Li}-\mathrm{S})$ cells are likely to become the next generation of energy storage to replace them.

One of the reasons is that sulfur is an abundant element so it's more affordable than cobalt used in Li-Ion cells. On top of that, Li-S cells are safer and more environmentally friendly. But the main advantage of this technology is the high energy density: around 5 times higher than Li-Ion cells.

The major obstacle for application is due to dissolved polysulfide shuttling between anode and cathode. This phenomeno leads to permanent loss of active mass from the cathode into the electrolyte and onto the Li metal anode (passivating the $\mathrm{Li}$ anode with insoluble $\mathrm{Li}_{2} \mathrm{~S}$ ), severe self-discharge, low efficiency and fast capacity decay.

Airbus DS has been testing and characterizing prototype Li-S cells manufactured by OXIS Energy Ltd. since 2014, demonstrating the potential and fast evolution of the cells performance. This paper presents the last test results on a set of different batches provided by OXIS and performed at Airbus DS premises in the frame of an ESA Innovation Triangle Initiative (ITI).
\end{abstract}

\section{INTRODUCTION}

This paper will first present a brief state of the art on Lithium-Sulfur technology, followed by the description of OXIS' cells tested during this study. After that, the test plan is described and the test results summarized and analysed to illustrate the current state of Li-S technology and its astonishing evolution.

\section{STATE OF THE ART}

A Lithium-Sulfur Battery (LSB) is a secondary battery composed of lithium metal anode and sulfur-based cathode.

The trend for the secondary battery requirements is to be cheaper, safer, environmentally friendly and especially to have a high energy density.

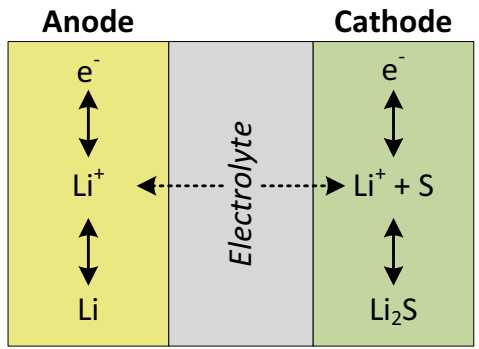

Figure 1: Lithium-Sulfur electrochemical process

The Li-S battery works on the basis of redox reactions between lithium metal anode and sulfur cathode. The reaction in Li-S battery is a reversible conversion reaction. The sulfur cathode offers a theoretical capacity of $1675 \mathrm{mAh} / \mathrm{g}$ and a theoretical energy density of 2600 $\mathrm{Wh} / \mathrm{kg}$ with the full utilization of sulfur in the following process:

$$
16 \mathrm{Li}^{+}+\mathrm{S}_{8}+16 \mathrm{e}^{-} \leftrightarrow 8 \mathrm{Li}_{2} \mathrm{~S}
$$

Lithium-sulfur secondary battery technology is currently the only rechargeable battery technology that can reach $400 \mathrm{Wh} / \mathrm{kg}$ energy density and 1350 cycles [RD1]. A better understanding and further research about the problems of this new technology could allow reaching even higher energy density in the future.

\subsection{Cathode materials}

Elemental sulfur is an attractive choice as a cathode material for high-specific-energy rechargeable lithium cells because of its high theoretical specific capacity and the fact that it is very low cost and non-toxic. Sulfur can react with lithium ions between 1.5 and $3.0 \mathrm{~V}$ (vs. 
$\mathrm{Li} / \mathrm{Li}^{+}$) producing soluble and insoluble lithium polysulfides. A major drawback of sulfur is its low electronic conductivity $\left(5 \times 10^{-30} \mathrm{~S} / \mathrm{cm}\right.$ at $\left.25{ }^{\circ} \mathrm{C}\right)$ compared to the cathode materials used for Li-Ion batteries. In comparison to Sulphur, carbon based cathodes have several orders of magnitude higher conductivity values. For example, the conductivity of MCMB (MesoCarbon MicroBeads) is around $10^{3} \mathrm{~S} / \mathrm{cm}$.

\subsection{Anode materials}

In the Li-S cells, dendrite deposition of Li metal is not as severe as observed in other lithium cell systems. This is attributed to the dissolved polysulfides (PS), which react with the anode and prevent the growth of $\mathrm{Li}$ dendrites.

Actually, while facilitating cell performance, the dissolved PS causes severe redox shuttle between the sulfur cathode and $\mathrm{Li}$ anode, which results in low columbic efficiency for charging and a fast selfdischarge rate for storage [RD2].

\subsection{Electrolyte}

PS anions and anionic PS radicals are extremely reactive, they participate in many types of reactions such as basic, nucleophilic, redox, and radical reactions. PS is known to react with most of the common electrolyte solvents, such as esters, carbonates, and phosphates. It appears that the suitable solvents for the Li-S cell electrolytes are limited within the linear and cyclic ethers, such as dimethyl ether (DME) and 1, 3dioxolane (DOL).

So far, Lithium trifluoromethanesulfonate (or lithium triflate) $\quad \mathrm{LiSO}_{3} \mathrm{CF}_{3}$ and lithium bis(trifluoromethanesulfony)amide (or LiTFSA) $\mathrm{LiN}\left(\mathrm{SO}_{2} \mathrm{CF}_{3}\right)_{2}$ have been reported to be the most suitable salt for the electrolyte of Li-S cells, of which $\mathrm{LiN}\left(\mathrm{SO}_{2} \mathrm{CF}_{3}\right)_{2}$ is superior in providing higher ionic conductivity and less corrosion to the Al substrate [RD30].

\subsection{Electrochemical behaviour}

Based on the phase change of sulfur species, the discharge process can be divided into four reduction regions (see Figure 2):

-Region I: a solid / liquid two-phase reduction from elemental sulfur to $\mathrm{Li}_{2} \mathrm{~S}_{8}$, which shows the first upper voltage plateau at $2.2-2.3 \mathrm{~V}$. In this region, the formed $\mathrm{Li}_{2} \mathrm{~S}_{8}$ dissolves into liquid electrolyte to become a liquid cathode. This process leaves numerous voids in the cathode.

-Region II: a liquid / liquid single-phase reduction from the dissolved $\mathrm{Li}_{2} \mathrm{~S}_{8}$ to low- order PS, during which the cell voltage steeply declines and the solution's viscosity gradually increases with a decrease in the length of S-S chain and an increase in the number (concentration) of PS anions. The solution's viscosity reaches a maximum value in the end of the discharge region.

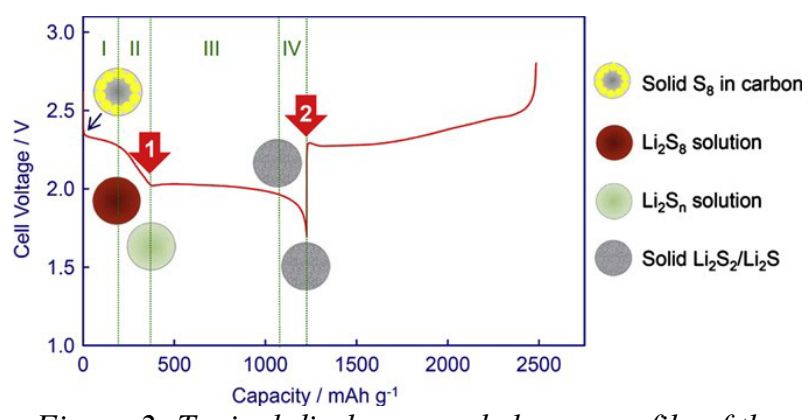

Figure 2: Typical discharge and charge profile of the first cycle of Li-S cells [RD3]

- Region III: a liquid / solid two-phase reduction from the dissolved low-order PS to insoluble $\mathrm{Li}_{2} \mathrm{~S}_{2}$ or $\mathrm{Li}_{2} \mathrm{~S}$, during which the following equations are competing with each other. This region forms the second lower voltage plateau at $1.9-2.1 \mathrm{~V}$, which contributes to the major capacity of a Li-S cell.

-Region IV: A solid / solid reduction from insoluble $\mathrm{Li}_{2} \mathrm{~S}_{2}$ to $\mathrm{Li}_{2} \mathrm{~S}$. This process is kinetically slow and generally suffers from high polarization due to the nonconductive and insoluble natures of $\mathrm{Li}_{2} \mathrm{~S}_{2}$ and $\mathrm{Li}_{2} \mathrm{~S}$.

Among the four regions above, Regions I and II show the highest redox shuttle, during which the cell suffers from the highest self-discharge rate and the cell's theoretical capacity can be seldom obtained. Region III contributes to the major capacity of a Li-S cell. Region IV becomes very short or even vanishes.

\subsection{Safety}

Li-S secondary batteries have demonstrated safe performance consistent with the technology's current state of development. Failures of early prototypes have been experienced, but they are of a magnitude and type that will yield to improvements in cell chemistry, packaging and electronic controls for cell charge / discharge management. It has to be noted that no fire or explosion occurred during the tests performed in the frame of the study.

The research and development areas specifically targeted to enhance Li-S battery safety are:

-Electrode stabilization,

-Electrolyte composition,

-Electronic controls and packaging designs internal and external to the cell. 


\section{OXIS LITHIUM-SULFUR CELLS}

OXIS provides different cells to be tested at Airbus DS facilities in order to analyse the evolution of the performances. Different batches of 5-6 cells have been specified:

- Batch 1a: Ultra-light cells of 6.5A.h with an energy density of $250 \mathrm{Wh} / \mathrm{kg}$;

- Batch 1b: Long-life cells of 10A.h with an energy density of $150 \mathrm{Wh} / \mathrm{kg}$;

- Batch 2: Ultra-light cells of 12A.h with an energy density around $300 \mathrm{Wh} / \mathrm{kg}$;

- Batch 3: Long-life cells of 20A.h with an energy density of $190 \mathrm{Wh} / \mathrm{kg}$.

The cells currently under test are described hereafter.

\subsection{OXIS POA0084 6.5Ah Ultra-Light Pouch Cells}

The main characteristics of the POA0084 Ultra-Light cells are listed in the following table.

\begin{tabular}{|c|c|}
\hline \multicolumn{2}{|c|}{ OXIS POA0084 6.5Ah Ultra-Light Pouch Cells } \\
\hline Nominal Voltage & $2.1 \mathrm{~V}$ \\
\hline Cell capacity & $\begin{array}{c}6.5 \mathrm{Ah}\left(0.2 \mathrm{C}, 20^{\circ} \mathrm{C} \text { to }\right. \\
1.9 \mathrm{~V})\end{array}$ \\
\hline Cell dimensions & $146 \times 76 \times 7 \mathrm{~mm}$ \\
\hline Cell mass & $55 \mathrm{~g}$ \\
\hline Specific energy & $248 \mathrm{Wh} / \mathrm{kg}$ \\
\hline Operating temperature & $5^{\circ} \mathrm{C}$ to $+30^{\circ} \mathrm{C}$ \\
\hline
\end{tabular}

Table 1: OXIS POA0084 6.5Ah Ultra-Light Pouch Cells characteristics

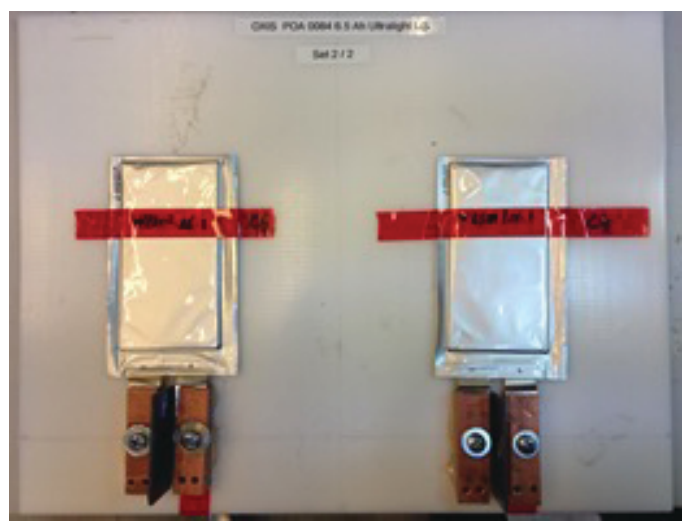

Figure 3: Test set-up for Li-S POA0084

\subsection{OXIS POA0122 10Ah Long Life Cells}

The main characteristics of the POA0122 Long Life cells are listed in the following table.

\begin{tabular}{|l|c|}
\hline \multicolumn{2}{|c|}{ OXIS POA0122 10Ah Long Life Cells } \\
\hline Nominal Voltage & $2.05 \mathrm{~V}$ \\
\hline Cell capacity & $\begin{array}{c}10 \mathrm{Ah}\left(2.3 \mathrm{~A}, 30^{\circ} \mathrm{C} \text { to }\right. \\
1.5 \mathrm{~V})\end{array}$ \\
\hline Cell dimensions & $174 \times 112 \times 7.3 \mathrm{~mm}$ \\
\hline Cell mass & $135 \mathrm{~g}$ \\
\hline Specific energy & $152 \mathrm{Wh} / \mathrm{kg}$ \\
\hline Operating temperature & $5^{\circ} \mathrm{C}$ to $+60^{\circ} \mathrm{C}$ \\
\hline
\end{tabular}

Table 2: OXIS POA0122 10Ah Long Life Cells characteristics

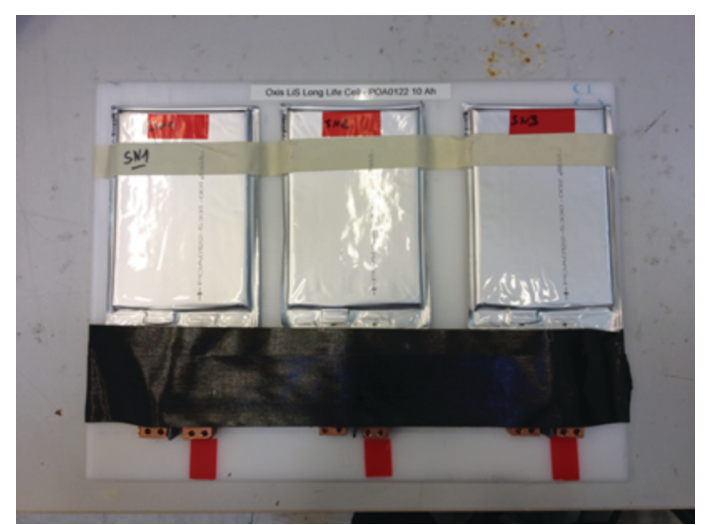

Figure 4: Test set-up for Li-S POA0122

\subsection{OXIS POA0217 12Ah Ultra-Light Pouch Cells}

The main characteristics of the POA0217 Ultra-Light cells are listed in the following table.

\begin{tabular}{|l|c|}
\hline \multicolumn{2}{|c|}{ OXIS POA0217 12Ah Ultra-Light Pouch Cells } \\
\hline Nominal Voltage & $2.1 \mathrm{~V}$ \\
\hline Cell capacity & $\begin{array}{c}12 \mathrm{Ah}\left(0.2 \mathrm{C}, 30^{\circ} \mathrm{C} \text { to }\right. \\
1.9 \mathrm{~V})\end{array}$ \\
\hline Cell dimensions & $174 \times 112 \times 7.3 \mathrm{~mm}$ \\
\hline Cell mass & $90 \mathrm{~g}$ \\
\hline Specific energy & $300 \mathrm{Wh} / \mathrm{kg}$ at $0.2 \mathrm{C}$ and \\
$30^{\circ} \mathrm{C}$
\end{tabular}

Table 3: OXIS POA0217 12Ah Ultra-Light Pouch Cells characteristics 


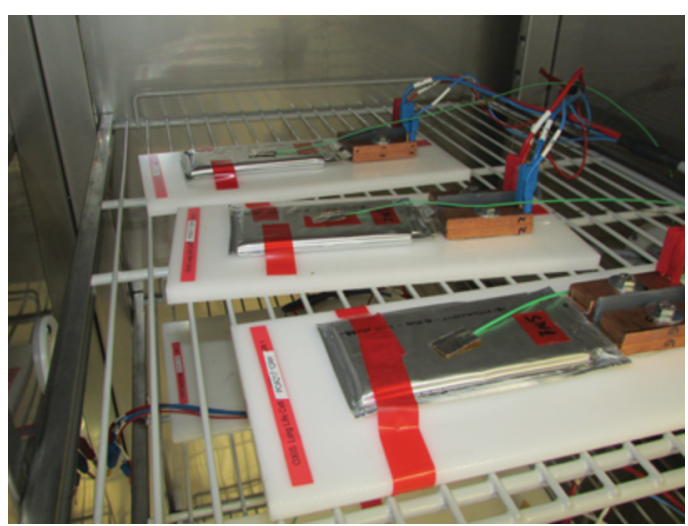

Figure 5: Test set-up for Li-S POA0217

\section{TEST PLAN}

The test plan is designed to evaluate the interest of this technology for space systems. For each cell batch delivery, the following tests will be performed.

\subsection{Initial Reference test}

The objective of this test is to confirm the characteristics shown on OXIS' datasheet. It is performed at the temperature indicated on the datasheet for the capacity measurement and performed at $\mathrm{C} / 5$ with internal resistance measurements at $0,10,20,60,80$ and $100 \%$ of Depth of discharge (DoD).

In order to assess the self-discharge, two reference tests will be performed: a first one with the discharge starting just after the end of the charge and a second one with one hour pause between the two phases.

\subsection{LEO cycling test}

If Li-S is meant to be used for satellite applications, it will need to face a high number of cycles representative of any LEO mission. For this test, a discharge at $\mathrm{C} / 3$ down to $20 \%$ of DoD has been selected with a charge rate of $\mathrm{C} / 5$. A hysteresis method is selected for charge management, so the voltage of the cell is always higher than end of charge voltage (EOCV) $-100 \mathrm{mV}$.

\subsection{GEO cycling test}

GEO missions based on Li-Ion technology use high discharge currents but such high currents are currently one of the weak points of Li-S. A test of cycling at $80 \%$ DoD and another one following a real GEO season profile are performed. The impact of EoCV is also assessed by performing one test at $80 \%$ DoD with the maximum voltage as EoCV and another one with a reduced $\mathrm{EoCV}$, expecting to increase the life of the cell, even if slightly degrading the total capacity.

After testing the first batch of cells (POA0084) at C/1.5, it was observed that the cell did not achieve the required capacity. It was then decided to characterize the discharge currents and perform a GEO cycling at $\mathrm{C} / 5$.

\subsection{Launcher test}

The wide temperature range expected for Li-S batteries make them very attractive for launcher applications since they often require starting at very low temperatures. A power profile coming from an Ariane 5 GTO DDO mission is run on one cell.

\subsection{Cells characterisation tests}

The last type of tests includes the characterisation of the cells at different temperatures: $+20^{\circ} \mathrm{C}$ for comparison and minimum and maximum temperatures included in the datasheet. The discharge is performed at $\mathrm{C} / 5$ with internal resistance measurements as per the reference test.

Current rates tests are done at Reference test temperature and at $\mathrm{C} / 5, \mathrm{C} / 2$ and $\mathrm{C}$ rates for discharge.

\section{TEST RESULTS}

\subsection{Initial Reference test}

At the time of writing, the tests results available are those on POA0084 Ultra-Light cells and POA0122 Long-Life cells. Partial results are available for the POA0217 Ultra-light cellS.
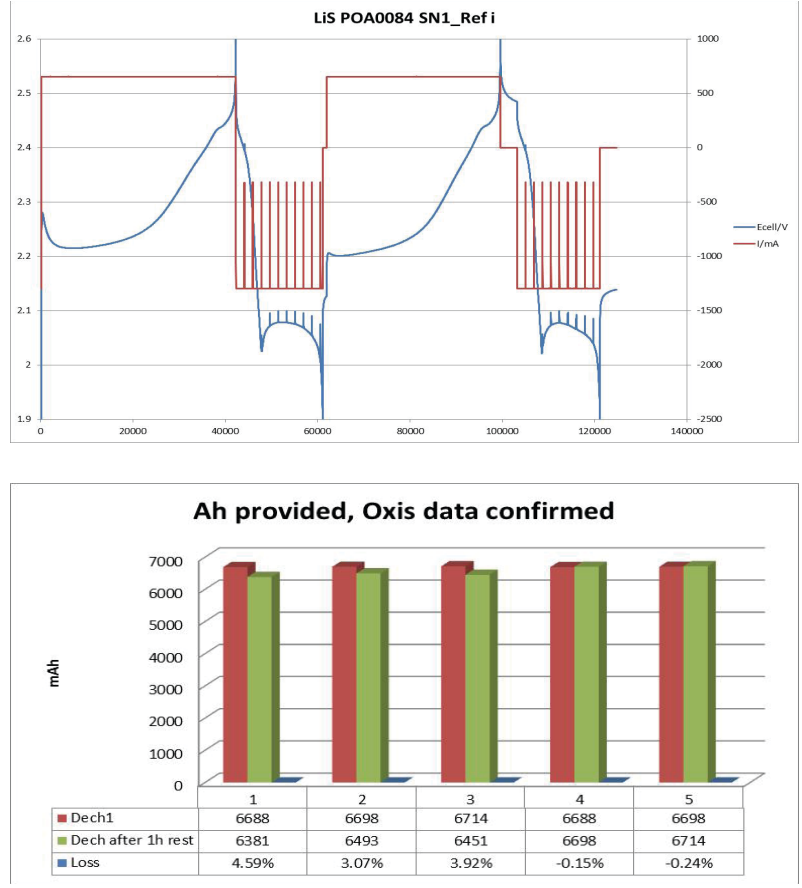

Figure 6: Initial Reference Test on Li-S POA0084

As it can be observed, the POA0084 capacity of $6.5 \mathrm{Ah}$ is confirmed by all the cells. The self-discharge after one hour in open-circuit varies from $4.6 \%$ to $0 \%$. 


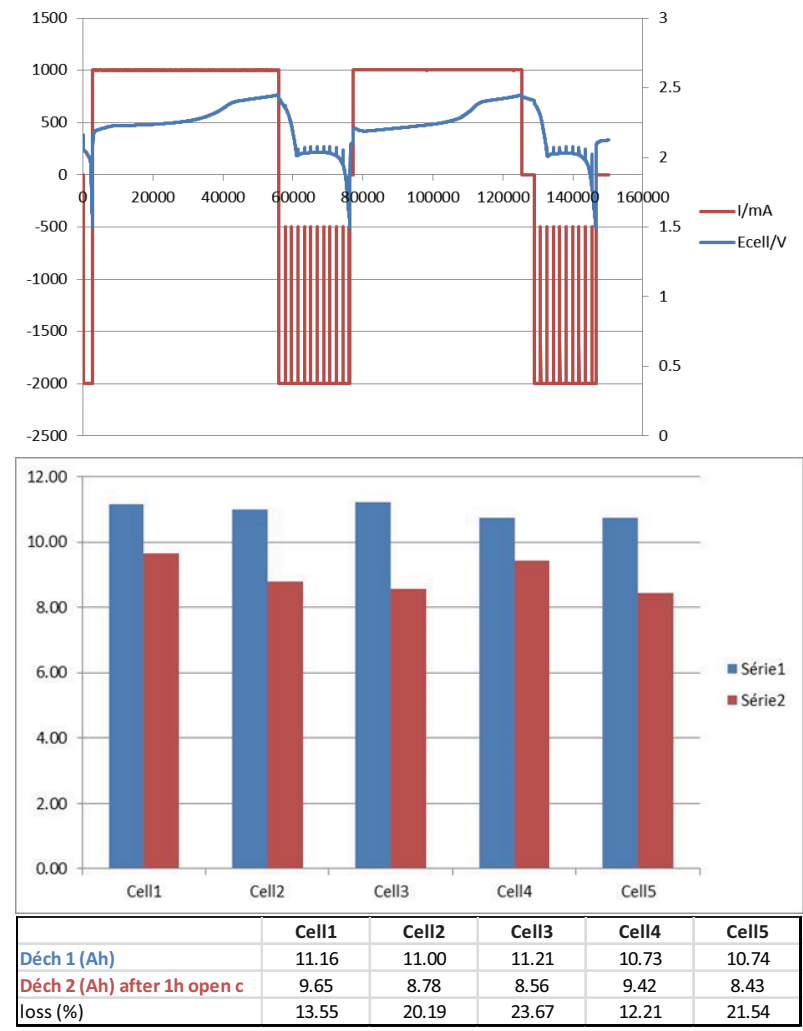

Figure 7: Initial Reference Test on Li-S POA0122

As it can be observed, the cell capacity shows always values higher than 10 A.h. However, in this type of cell the self-discharge is more important: between $12 \%$ and $24 \%$ of loss capacity in just one hour of open-circuit.

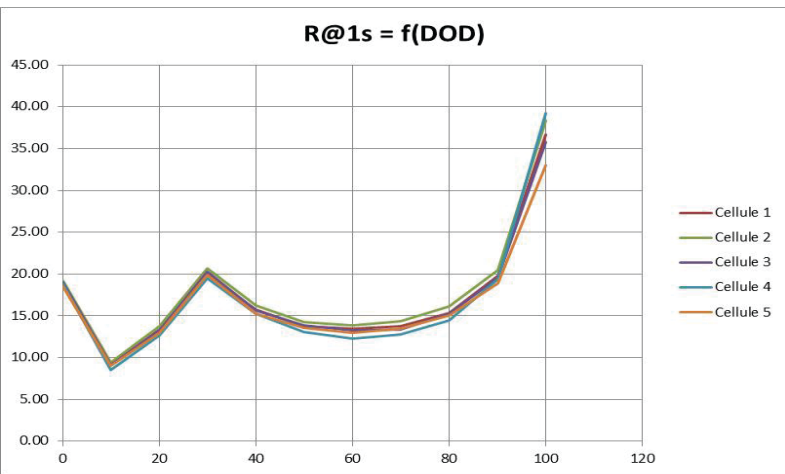

Figure 8: Internal Resistance at 1s on Li-S POA0084 depending on the DoD

Internal resistance measurements, with the Ultra Light Cells, show values between $10 \mathrm{~m} \Omega$ and $40 \mathrm{~m} \Omega$ (at $1 \mathrm{~s}$ ) depending on the DoD. All the five cells show the same trend. Measurements at $30 \mathrm{~s}$ can go up to $80 \mathrm{~m} \Omega$.

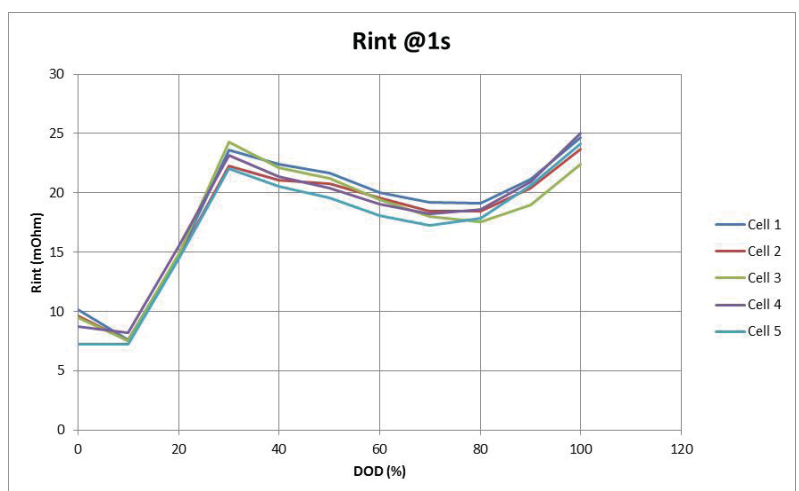

Figure 9: Internal Resistance at 1s on Li-S POA0122 depending on the DoD

Internal resistance measurements, with the long life cells, show values between $7 \mathrm{~m} \Omega$ and $25 \mathrm{~m} \Omega$ (at $1 \mathrm{~s}$ ) depending on the DoD (much lower than the Ultra-light cells). All the five cells show the same trend.

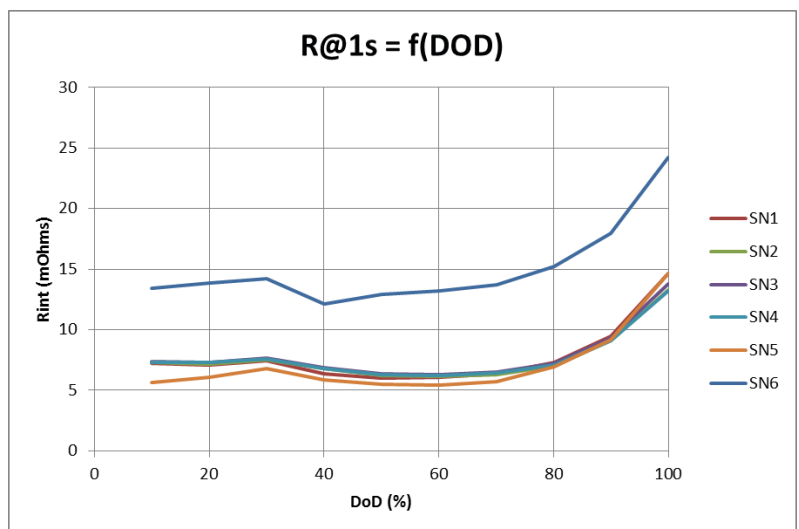

Figure 10: Internal Resistance at 1s on Li-S POA0217 depending on the DoD

A new batch of Ultra-light cells shows a lower internal resistance that the first one. The resistance values decreased from a range of 10 to $40 \mathrm{~m} \Omega$ (at $1 \mathrm{~s}$ ) down to 5 to $15 \mathrm{~m} \Omega$ (at $1 \mathrm{~s})$ for five out of six samples.

\subsection{LEO cycling test}

In figure 11 the hysteresis method for charge management can be observed: once the EOCV $(2.6 \mathrm{~V})$ is reached, the charge ends, the cell voltage goes down progressively and reaches $2.5 \mathrm{~V}$ (EOCV-100mV) just when the discharge phase starts. 


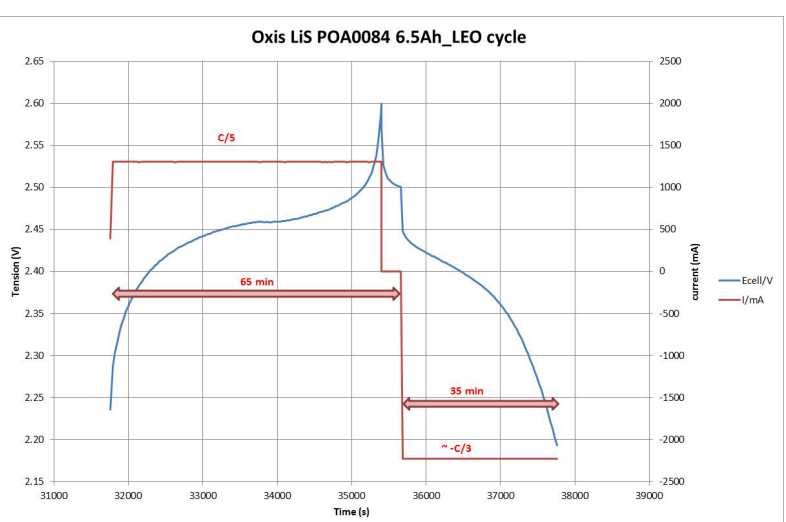

Figure 11: LEO cycling Test on Li-S POA0084

The evolution of the End Of Discharge voltage shows the progressive loss of capacity.

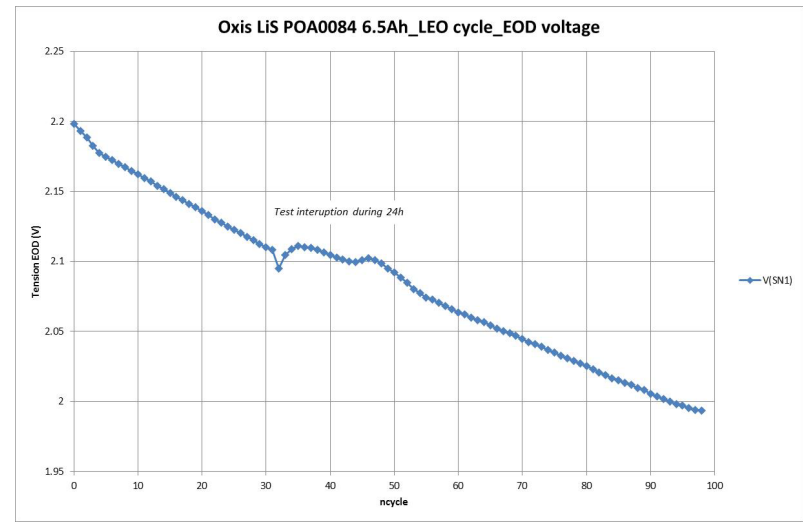

Figure 12: EODV evolution during LEO cycling Test on Li-S POA0084

At the time of writing, the POA0217 Ultra-Light cell has completed 55 cycles and the test is still running. The next table summarizes the performance of the other cells.

\begin{tabular}{|l|c|}
\hline & 20\% DoD cycles \\
\hline Ultra-light POA0084 6.5Ah & 98 \\
\hline Long-life POA0122 10Ah & 100 \\
\hline Ultra-light POA0217 12Ah & $>55$ so far \\
\hline
\end{tabular}

Table 4: Number of LEO cycles at 20\% DoD performed

\subsection{GEO cycling test}

GEO cycling was initially foreseen with a discharge rate of $\mathrm{C} / 1.5$ but as it can be observed, the value of $\mathrm{Ah}$ expected (5.2Ah) was higher than the capacity that could be actually provided (3.97Ah).

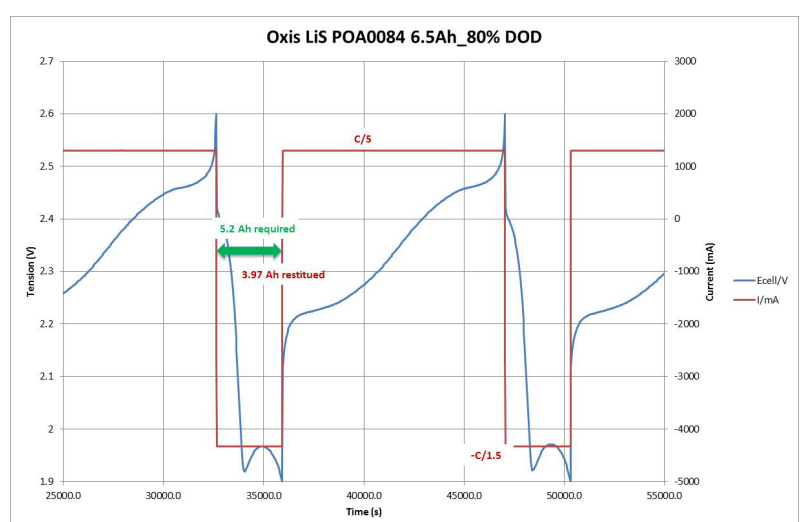

Figure 13: GEO cycling Test on Li-S POA0084

Unlike LEO cycling, the cell cannot provide enough capacity. The test was stopped when the fading reached $83 \%$.

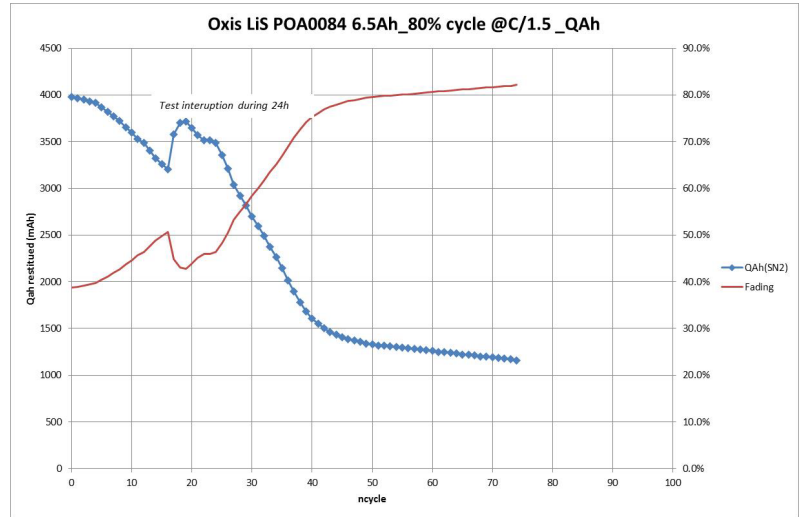

Figure 14: Fading and capacity provided during GEO cycling Test on Li-S POA0084

The cell following a real GEO eclipse season could provide enough capacity until eclipse number 8 .

It was then decided to assess higher levels of DoD at lower discharge currents: $\mathrm{C} / 5$ instead of $\mathrm{C} / 1.5$.

At the time of writing, the POA0217 Ultra-Light cell has completed 25 cycles and the test is still running. The next table summarizes the performance of the other cells.

\begin{tabular}{|l|c|}
\hline & $\mathbf{8 0 \%}$ DoD cycles \\
\hline Ultra-light POA0084 6.5Ah & 73 \\
\hline Long-life POA0122 10Ah & 48 \\
\hline Ultra-light POA0217 12Ah & $>25$ so far \\
\hline
\end{tabular}

Table 5: Number of cycles at 80\% DoD performed

\subsection{Launcher test}

As explained, a power profile coming from an Ariane 5 GTO DDO mission has been run on one cell per batch. 


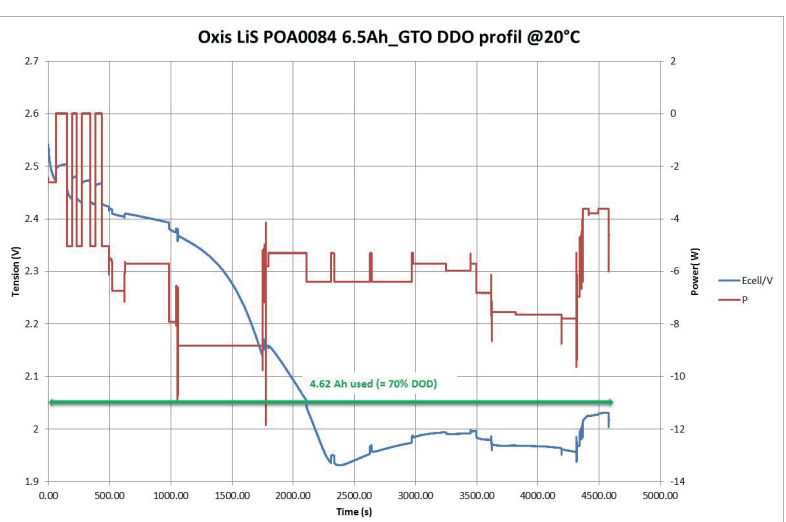

Figure 15: Launcher profile Test on Li-S POA0084

The launcher profile test showed that the cell could withstand without any problem this type of mission. The DoD reached at the end of the mission was $70 \%$, letting enough margin for its application.

The two other cells passed without any problem the adapted launcher profile.

\subsection{Cells characterisation tests}

Characterisation tests include discharge at different current rates and temperature values. As it has already been demonstrated by the GEO cycling, the discharge current clearly impacts the capacity that can be provided by the cell. $\mathrm{C} / 5$ guarantees the nominal capacity, but when it is increased up to $\mathrm{C} / 2$ this is reduced by $22 \%$. At $0.75 \mathrm{C}$, the capacity is reduced by $75 \%$.

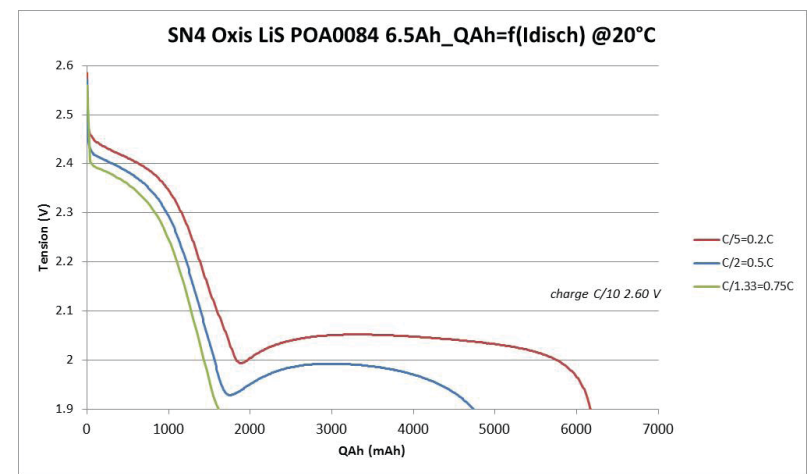

Figure 16: C-rate characterisation Test on Li-S POA0084

The tolerance to high C-rates has been considerably enhanced with the new batch of Ultra-light cells, reducing the loss from $75 \%$ down to $27 \%$ as it can be observed on the next figure.

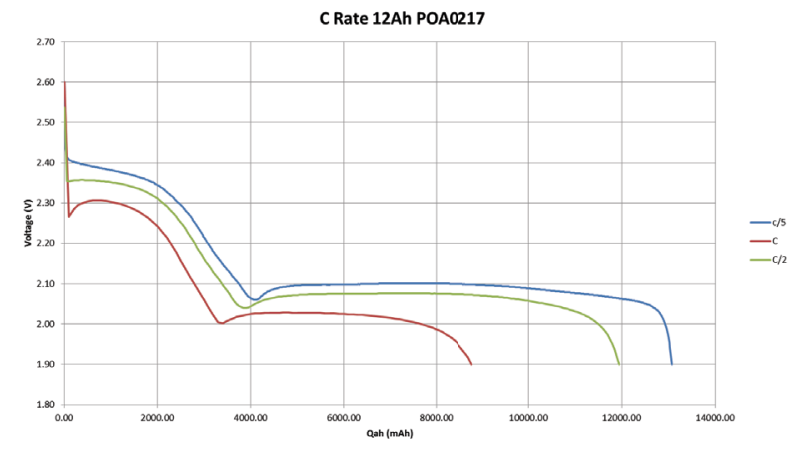

Figure 17: C-rate characterisation Test on Li-S POA0217

The following figures show that the impact at capacity and internal resistance level increases when the temperature decreases. No dramatic differences are observed for $+20^{\circ} \mathrm{C}$ and $+30^{\circ} \mathrm{C}$ but a huge capacity loss appears at $+5^{\circ} \mathrm{C}$.
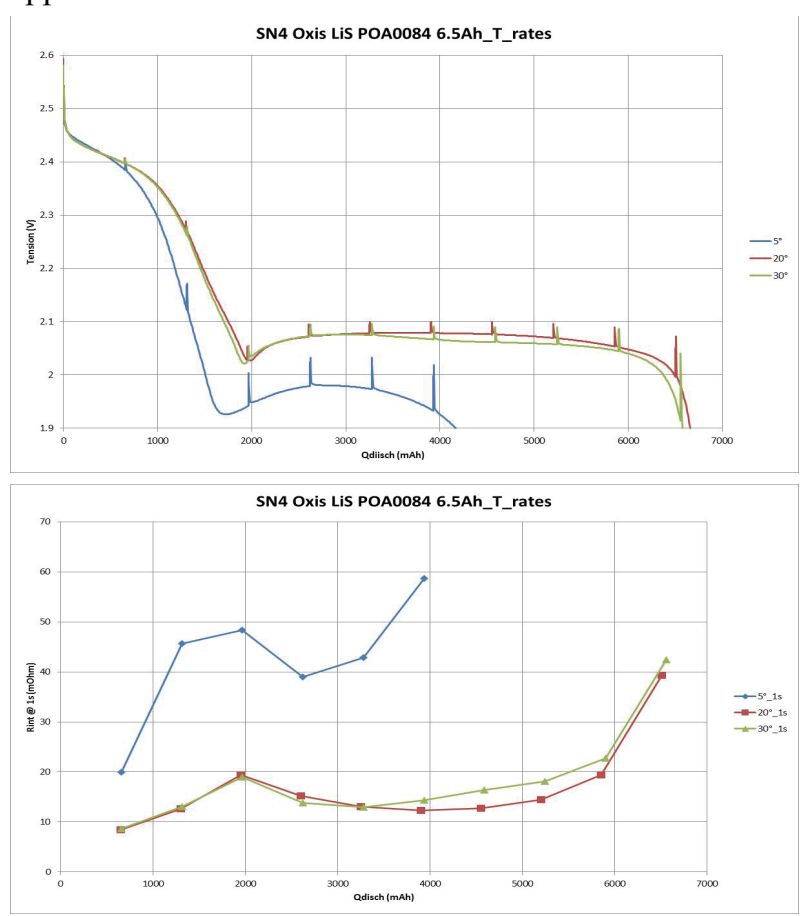

Figure 18: Temperature characterisation Test on Li-S POA0084

Again, this issue has been assessed for the last batch of Ultra-Light cells, reducing the sensitivity to the temperature. Again, as it can be observed on the figure below, no major difference appears between $+20^{\circ} \mathrm{C}$ and $+30^{\circ} \mathrm{C}$, but the difference with regard to the $+5^{\circ} \mathrm{C}$ case has been considerably reduced. 


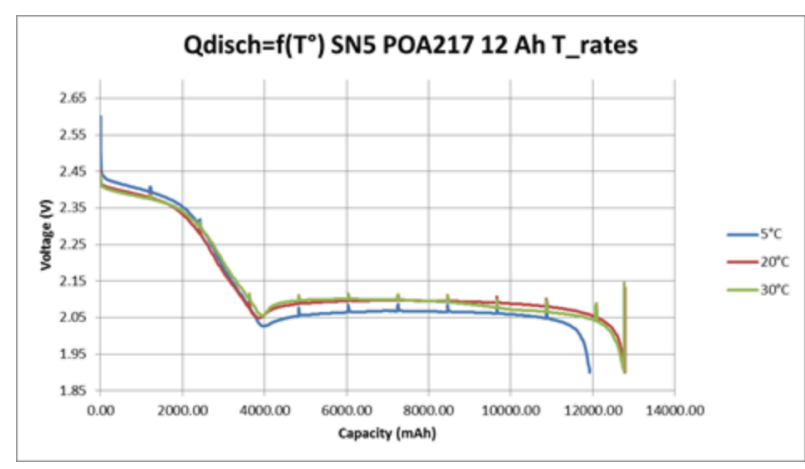

Figure 19: Temperature characterisation Test on Li-S POA0217

POA0122, can operate at a higher maximum temperature $\left(+60^{\circ} \mathrm{C}\right)$ and provides a similar capacity compared to $+30^{\circ} \mathrm{C}$.

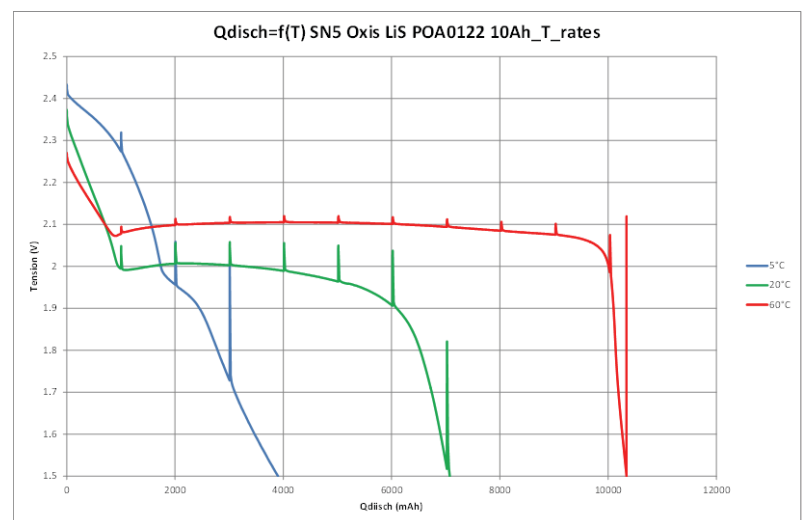

Figure 20: Temperature characterisation Test on Li-S POA0122

\section{CONCLUSION}

At the time of writing, only two cells have been fully tested and the newer versions of them can show only partial results. However, some conclusions can be drawn.

- It is demonstrated by testing that Li-S is a technology with a specific energy superior to that of Li-Ion, i.e $306 \mathrm{Wh} / \mathrm{kg}$ delivered by a POA0217 Ultra-light cell at Airbus DS premises.

- The major drawback of Li-S batteries for spacecraft applications continues to be the cycling capability. Up to now, only 100 cycles have been achieved at a $20 \%$ DoD. An additional cell has been provided by OXIS for batches 2 and 3 in order to study the impact of EoCV but there are no significant results at the time of writing. However, background from previous tests performed by OXIS and Airbus DS has shown a much higher cycling capability on other Li-S cells by reducing the EoCV (up to 1400 cycles at $20 \%$ DoD with a capacity loss of $15 \%$ ) by reducing for instance the voltage from $2.6 \mathrm{~V}$ down to $2.45 \mathrm{~V}$. Similar results are expected to be obtained with the additional cells under test for batch 2 and 3 . If the cycling capability proves to indeed be significantly improved by a $150 \mathrm{mV}$ reduction in EoCV also for this latest Li-S technology, it would be worth considering for certain mission profiles. Thanks to the significant leap in specific energy for Li-S batteries compared to the Li-ion ones, despite the for-mentioned decrease of the EoCV, Li-S batteries would still deliver a higher specific energy compared to Li-ion.

- Two of the main drawbacks up to now such as the dependency of the capacity on the temperature and the current rate have been addressed.

Despite the limitations to this moment, Li-S battery technology shows a great potential for many space applications like launchers or LEO satellite missions. Performances regarding cycling, rate capability and temperature need to be however further improved.

Li-S technology is just at the beginning and already shows great potential and constant evolution. The results of the tests performed during this ITI are encouraging and suggest that Li-S will in fact become the next generation of energy storage.

\section{REFERENCES}

RD 1: Min-Kyu Song, Yuegang Zhang and Elton J. Cairns "A Long-Life, High-Rate Lithium/Sulfur Cell: A Multifaceted Approach to Enhancing Cell Performance" - Nano letters, 2013 - ACS Publications

RD 2: Y.V. Mikhaylik and al., "High energy rechargeable Li-S cells for EV application: status, remaining problems and solutions", ECS Transactions, vol.25, $\mathrm{n}^{\circ} 35$, pp. 23-34, 2010

RD 3: S. S. Zhang, "liquid electrolyte lithium / sulfur battery: fundamental chemistry, problems, and solutions", Journal of Power Sources 231 (2013) 153 $-162$

RD 4: Test plan for $\mathrm{Li}-\mathrm{S}$ cells, 2125.SP.CE.16. 2177.ASTR, Issue 02 